\title{
The Effect of Management of Transport and Lairage Conditions on Broiler Chicken Breast Meat Quality and DOA (Death on Arrival)
}

\author{
Alexandre Oba ${ }^{1 *}$, Mauricio de Almeida ${ }^{1}$, João Waine Pinheiro ${ }^{1}$, Elza Iouko Ida ${ }^{2}$, Denis \\ Fabricio Marchi ${ }^{2}$, Adriana Lourenço Soares ${ }^{2}$ and Massami Shimokomaki ${ }^{2}$ \\ ${ }^{1}$ Departamento de Zootecnia; Universidade Estadual de Londrina; 86051-970; Londrina - PR - Brasil. \\ ${ }^{2}$ Departamento de Ciência e Tecnologia de Alimentos; Centro de Ciências Agrárias; Universidade Estadual de \\ Londrina; 86051-970; Londrina - PR - Brasil
}

\begin{abstract}
The aim of this work was to evaluate the influence of time of broiler chicken transportation and lairage prior to slaughtering on the occurrence of PSE (Pale, Soft, Exudative) meat and Death On Arrival (DOA) under noncommercial conditions in the Brazilian summer. Male birds $(n=250)$ from a commercial line were subjected to different periods of journey $(30,90$, and $180 \mathrm{~min})$ and lairage $(0,90$, and $180 \mathrm{~min})$ before slaughtering. The occurrence of PSE was higher in broilers subjected to shorter journeys and lairage periods, whereas DOA was more pronounced upon longer periods of transport and lairage. The DOA occurrence percentage was much higher in comparison to commercially available figures, confirming that broiler chickens are very sensitive to both transport and lairage maneuvers.
\end{abstract}

Key words: water holding capacity, PSE meat, color abnormalities, broiler management

\section{INTRODUCTION}

Broilers chicken welfare has been a challenge for the poultry industry, and proper management is a topic to be aware to avoid the stressful conditions that can lead to compromise meat quality, as in the case of PSE (Pale, Soft and Exudative) meat, and DOA (Dead on Arrival) (Mitchel and Kettlewell, 1998, Barbut et al. , 2008, Olivo and Shimokomaki, 2006). PSE meat originates from a rapid decline in $\mathrm{pH}$ while the carcass of the animal is still hot, leading to the denaturation of myofibril proteins thus compromising their functional properties (Sosnicki et al., 1998, Olivo et al.,
2001). Several pre-slaughtering factors are related to broiler PSE meat formation, particularly transport, lairage, and slaughtering conditions. Journey maneuvers from the farm to the slaughterhouse, such as showering the birds at the farm, heat, vehicle acceleration, vibration, movement, impact, food and water deprivation, social disruption, and noise, are especially important (Mitchell and Kettewell 1998, Simões et al., 2009a, b). In fact, heat stress during truck transport is one of the main causes of DOA and PSE development (Mitchell and Kettewell 1998, Langer et al. 2009, Simões et al. 2009a, b). As reported by Warriss et al. (1992) and Petracci et al.

*Author for correspondence: oba@uel.br 
(2006), one of the main causes of DOA is the management during transport and that thermal stress leads to the increased mortality percentage. Thus, the aim of this work was to evaluate the influence of transport period and lairage on breast meat quality and the DOA rate under noncommercial management prior to broiler slaughtering.

\section{MATERIALS AND METHODS}

\section{Animals and management}

This experiment was carried out in the summer season at the Farm School of Universidade Estadual de Londrina and dealt with 42day-old male broilers $(n=250)$ of commercial lineage. After an $8 \mathrm{~h}$ water only diet regime, birds were placed in boxes $(n=9)$ with dimensions of $772 \times$ $570 \times 303 \mathrm{~mm}$ and subjected to road conditions in an open truck at $33^{\circ} \mathrm{C}$ for transport periods of 30 , 90 , or $180 \mathrm{~min}$. Upon arrival at the slaughterhouse, birds were subjected to lairage under shade and natural ventilation for 0,90 or $180 \mathrm{~min}$ before slaughtering. Broilers were killed manually under laboratory conditions following the commercial procedures as closely as possible. This included cutting the carotid artery and jugular vein after electrical stunning, followed by scalding, feathering, eviscerating, and removing the breast muscle samples, which were kept refrigerated at $4^{\circ} \mathrm{C}$ for further analysis.

\section{pH and color measurements}

The $\mathrm{pH}$ of the samples was measured by inserting electrodes into the breast muscle, Pectoralis major $m$., using a pH meter system (Testo $205 \mathrm{pHmeter}$ ). The initial (pHi) and final (pHf) $\mathrm{pH}$ were measured at $15 \mathrm{~min}$ and $24 \mathrm{~h}$ postmortem at $4^{\circ} \mathrm{C}$ in triplicate, as reported in Olivo et al. (2001). A Minolta CR10 colorimeter was used to evaluate color, L*(lightness), $\mathrm{a}^{*}$, and $\mathrm{b}^{*}$ (CIELAB color system) on the posterior surface of the intact skinless breast muscle at $24 \mathrm{~h}$ postmortem. The color values were measured at three different sites on the same sample (Olivo et al., 2001).

\section{Samples classification}

Samples were classified as PSE or normal meat samples based on previously established parameters associated with $\mathrm{pH}$ and color values as $\mathrm{L}^{*} \geq 53.0$ for PSE, $\mathrm{L}^{*} \leq 44.0$ for DFD-like (Dry,
Firm, Dark), and $44.0<\mathrm{L}^{*}<53.0$ for normal groups (Soares et al., 2002).

\section{Water-holding capacity (WHC) measurement} WHC was determined based on a technique described by Hamm (1960). Twenty-four-hour postmortem the samples were collected from the cranial side of the breast fillets, cut into $2.0 \mathrm{~g}$ $( \pm 0.10 \mathrm{~g})$ cubes, and analyzed in duplicate. They were first carefully placed between two filter papers and then left under a $10.0 \mathrm{~g}$ weight for 5 min. The samples were weighed, and WHC was determined from the exudate water weight using the formula: $100-[(\mathrm{Wi}-\mathrm{Wf} / \mathrm{Wi}) \mathrm{x} 100]$, where $\mathrm{Wi}$ and Wf were the initial and final sample weights, respectively.

\section{Statistical analysis}

Data were analyzed by complete randomized design with a factorial of $3 \times 3$ (transport $\mathrm{x}$ lairage period) and 28 samples per treatment. Each bird represented an experimental unity. Tukey`s multiple range tests were used to determine significant differences $(\mathrm{P}<0.05)$ among chicken groups.

\section{RESULTS AND DISCUSSION}

\section{Transport and lairage conditions}

As shown in Table 1, the longer the transport period the higher was the percentage of birds weight lost the percentage of the birds weight that was lost $(\mathrm{P}<0.01)$. Also, lairage times up to $90 \mathrm{~min}$ led to a higher loss of weight thereafter there was no significant difference in weight loss. Table 2 shows the interrelationship between transport period and lairage on the birds weight loss. Birds subjected up to $30 \mathrm{~min}$ of transport presented the lowest percentage of weight loss compared to the 90 and $180 \mathrm{~min}$ transport periods. The combination of $180 \mathrm{~min}$ of transport time and 90 min of lairage was the worst condition, as the animals lost the highest percentage of their weight under these conditions $(\mathrm{P}<0.01)$. Since the birds were deprived of food and water, they lost water either during transport or lairage. However, these results are much higher than those reported by Bulgili et al. (1989) and Mendes et al. (2001), 0.5 and 2.0\%, respectively, during transport. Apparently under the conditions of these experiments, the birds never reached homeostasis, 
and there was therefore a need to control for these stressful harsh conditions. The routine commercial procedure involves a water shower treatment while at the farm and also before the slaughtering phase at the plant (Simões et al., 2009a, b).

Table 1 - The percentage weight loss in broilers during transport and lairage before slaughtering.

\begin{tabular}{cc}
\hline Treatments & Weight loss (\%) \\
\hline Transport period - T (min) & $2.41 \mathrm{c}$ \\
30 & $3.03 \mathrm{~b}$ \\
90 & $4.82 \mathrm{a}$ \\
180 & $114.59^{* *}$ \\
\hline F test & 0.39 \\
\hline MSD & $2.62 \mathrm{~b}$ \\
\hline Lairage - L (min) & $3.76 \mathrm{a}$ \\
90 & $3.88 \mathrm{a}$ \\
\hline F test & $35.25^{* *}$ \\
MSD & 0.39 \\
\hline CV & $7.05^{* *}$ \\
\hline
\end{tabular}

${ }^{1}$ Means followed by different letters in the same column are significantly different by Tukey test $(\mathrm{P}<0.01=* *)$. MSD: Minimum Significant Difference. CV: Coefficient of Variation.

Table 2 - Interrelationship between transport period and lairage in relation to broiler weight loss (\%)

\begin{tabular}{ccccc}
\hline \multirow{2}{*}{$\begin{array}{c}\text { Transport period } \\
\text { (min) }\end{array}$} & $\mathbf{0}$ & $\mathbf{9 0}$ & \multirow{2}{*}{ Lairage (min) } \\
\cline { 2 - 4 } & $1.45 \mathrm{bC}$ & $2.66 \mathrm{aB}$ & $3.12 \mathrm{aB}$ & $18.09^{* *}$ \\
90 & $2.56 \mathrm{bB}$ & $2.83 \mathrm{bB}$ & $3.69 \mathrm{aB}$ & $8.57^{* *}$ \\
180 & $3.85 \mathrm{cA}$ & $5.78 \mathrm{aA}$ & $4.83 \mathrm{bA}$ & $22.68^{* *}$ \\
F Test & $35.21^{* *}$ & $75.07^{* *}$ & $18.42^{* *}$ & \\
\hline
\end{tabular}

${ }^{\mathrm{A}-\mathrm{C}}$ Mean within columns with different superscripts are significantly different and ${ }^{\mathrm{a}-\mathrm{c}}$ mean within rows with different superscripts are significantly different by Tukey test $(\mathrm{P}<0,01=* *)$. MSD: Minimum Significant Difference for Tukey test of transport period and lairage $=0.68$.

\section{pH and WHC measurements}

Table 3 shows that there were no significant differences in pHi, pHf, and WHC values among samples. However, under the CIELAB system for breast meat color, differences were noted for $\mathrm{L}^{*}$ and $\mathrm{a}^{*}(\mathrm{P}<0.05)$ (Table 4). L values were lower in samples transported for $180 \mathrm{~min}$, and the while samples from 30 and $90 \mathrm{~min}$ were also different, although not significant. These results indicate that the $180 \mathrm{~min}$ journey was a highly stressful condition for the birds to be under, and changes observed within the breast meat samples were only significantly observed in color characteristics, with relatively lower $\mathrm{L}^{*}$ and higher $\mathrm{a}^{*}$, as seen in Table 4. The evaluated interrelationship between transport and lairage for the $30 \mathrm{~min}$ journey did not show any significant changes (Table 5). However, meat samples from birds transported for
90 min and not subjected to lairage presented lower $\mathrm{L}^{*}$ values in comparison to those subjected to lairage $(\mathrm{P}<0.05)$ for $90 \mathrm{~min}$. Birds subjected to $180 \mathrm{~min}$ of transport and lairage of $90 \mathrm{~min}$ presented lower $\mathrm{L}^{*}$, while those broilers subjected to $180 \mathrm{~min}$ of lairage or not subjected to lairage showed higher $\mathrm{L}^{*}$ values $(\mathrm{P}<0.01)$. These results are corroborated by other reports showing that for shorter journeys under Brazilian summer conditions there is as a consequence of higher $\mathrm{L}^{*}$ irrespective of lairage period (Langer, et al. , 2009, Simões et al., 2009a,b). The combination of longer journeys of $180 \mathrm{~min}$ with a lairage period of 90 min is adequate to allow the birds to reach their body homoeostasis. However, there is a limitation on lairage conditions due to feeding time, since longer fasting influences the meat $\mathrm{L}^{*}$ values. 
Table 3 - Initial (pHi 15 min) and final (pHf 24 h) pH and water holding capacity (WHC) values of breast meat 24 $\underline{\mathrm{h} \text { post-mortem for broilers subjected to different transport times and lairage. }}$

\begin{tabular}{cccc}
\hline Treatments & pHi & pHf & WHC \\
\hline Transport period - T (min) & & & 67.05 \\
30 & 6.56 & 5.89 & 68.48 \\
90 & 6.55 & 5.83 & 69.06 \\
180 & 6.55 & 5.79 & 2.38 \\
\hline F test & 0.64 & 1.79 & 2.27 \\
MSD & 0.62 & 0.13 & 67.06 \\
\hline Lairage - L (min) & & & 68.61 \\
(m0 & 6.54 & 5.84 & 68.92 \\
\hline F test & 6.53 & 5.87 & 2.22 \\
MSD & 6.59 & 5.81 & 2.27 \\
\hline F interaction T x L & 2.29 & 0.65 & 0.98 \\
\hline CV & 0.62 & 0.13 & 4.44 \\
\hline
\end{tabular}

MSD: Minimum Significant Difference CV: coefficient of variation.

Table 4 - Colour values of $\left(\mathrm{L}^{*}\right),\left(\mathrm{a}^{*}\right)$ and $\left(\mathrm{b}^{*}\right)$ for breast fillets from broilers subjected to different transport and lairage times and stored at $4 \mathrm{oC}$ for $24 \mathrm{~h}$.

\begin{tabular}{|c|c|c|c|}
\hline $\begin{array}{c}\text { Treatments } \\
\end{array}$ & $\mathbf{L}^{*}$ & $a^{*}$ & $\mathbf{b}^{*}$ \\
\hline \multicolumn{4}{|l|}{ Transport period $-\mathrm{T}(\mathrm{min})$} \\
\hline 30 & $55.50 \mathrm{a}^{1}$ & $1.68 \mathrm{~b}$ & 12.55 \\
\hline 90 & $55.50 \mathrm{a}$ & $1.86 \mathrm{ab}$ & 12.03 \\
\hline 180 & $54.34 \mathrm{~b}$ & $2.28 \mathrm{a}$ & 12.35 \\
\hline F test & $4.55 *$ & $4.04 *$ & 1.30 \\
\hline MSD & 1.04 & 0.51 & 0.79 \\
\hline \multicolumn{4}{|l|}{ Lairage - L (min) } \\
\hline 0 & 55.15 & 1.94 & 12.35 \\
\hline 30 & 54.93 & 1.99 & 12.46 \\
\hline 180 & 55.27 & 1.90 & 12.20 \\
\hline $\mathrm{F}$ test & 0.30 & 0.93 & 0.30 \\
\hline MSD & 1.04 & 0.51 & 0.79 \\
\hline $\mathrm{F}$ interaction $\mathrm{T} \times \mathrm{E}$ & $6.05 * *$ & 0.28 & 2.25 \\
\hline $\mathrm{CV}$ & 4.68 & 66.63 & 15.89 \\
\hline
\end{tabular}

${ }^{\mathrm{a}-\mathrm{c}}$ Mean within columns with different superscripts are significantly different by Tukey test $(\mathrm{P}<0.01=* *$ and $\mathrm{P}<0.05$ $=*) . \mathrm{CV}=$ Coefficient of variation. $\mathrm{NS}=$ non significant.

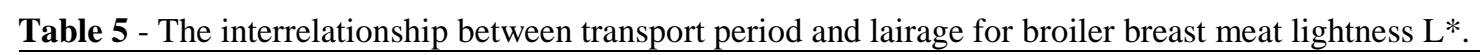

\begin{tabular}{ccccc}
\hline \multirow{2}{*}{ Transport period $(\min )$} & \multicolumn{3}{c}{ Lairage $(\mathbf{m i n})$} & \multirow{2}{*}{ F test } \\
\cline { 2 - 4 } & $\mathbf{0}$ & $\mathbf{9 0}$ & $\mathbf{1 8 0}$ & $0.41 \mathrm{NS}$ \\
90 & 55.64 & $55.76 \mathrm{~A}$ & 55.11 & $3.51^{*}$ \\
180 & $54.48 \mathrm{~b}$ & $56.51 \mathrm{aA}$ & $55.52 \mathrm{ab}$ & $8.49^{* *}$ \\
F test & $55.33 \mathrm{a}$ & $52.52 \mathrm{bB}$ & $55.17 \mathrm{a}$ & 0.17 \\
\hline
\end{tabular}

${ }^{\mathrm{A}-\mathrm{C}}$ Mean within columns with different superscripts are significantly different and ${ }^{\mathrm{a}-\mathrm{c}}$ mean within rows with different superscripts are significantly different by Tukey test $(\mathrm{P}<0.01=* *$ and $\mathrm{P}<0.05=*)$. Minimum Significant Difference (MSD) for Tukey test of transport period and lairage $=1.81$. NS $=$ non significant. 


\section{Evaluation of DOA and PSE meat}

Table 6 shows the results for DOA and PSE meat samples from birds subjected to different transport periods and lairage. These results clearly show the importance of the water-showering treatment, in particular, at the slaughterhouse plant, as is routinely performed commercially (Simões et al. , 2009a,b). In this experiment, there was a very high incidence of PSE meat irrespective of treatment conditions (Table 6). The highest percentage of PSE was observed with a transport time of $30 \mathrm{~min}$ and $0 \mathrm{~min}$ of lairage. However, as the lairage period increased, there was a concomitant decrease in the percentage of PSE meat. This is most likely due to the fact that during longer lairage times, there is the possibility of these animals gradually reaching homoeostasis. In fact, a high DOA percentage was observed without the birds resting, and gradually these animals reached homeostasis. Afterwards, under conditions of both longer journey time and lairage periods, there was an increase in DOA.

Table 6 - The percentage of death on arrival (DOA) and the occurrence of pale, soft, exudative (PSE) meat in broilers subjected to different pre-slaughtering management.

\begin{tabular}{ccccc}
\hline \multirow{2}{*}{$\begin{array}{c}\text { Transport / Lairage } \\
\text { Period }\end{array}$} & Total & Blive & DOA (\%) & PSE (\%) \\
\cline { 2 - 4 } $30 / 0$ & 28 & 25 & 10.7 & 92.0 \\
$30 / 90$ & 28 & 28 & 0 & 85.7 \\
$30 / 180$ & 28 & 28 & 0 & 71.4 \\
$90 / 0$ & 28 & 28 & 0 & 60.7 \\
$90 / 90$ & 28 & 28 & 0 & 82.3 \\
$90 / 180$ & 28 & 27 & 3.5 & 81.5 \\
$180 / 0$ & 28 & 25 & 10.7 & 84.0 \\
$180 / 90$ & 28 & 12 & 57.1 & 50.0 \\
$180 / 180$ & 28 & 19 & 32.1 & 63.1 \\
\hline
\end{tabular}

In an experiment carried out in the UK by Warriss et al. (1992), for journeys lasting less than $4 \mathrm{~h}$ the incidence of dead birds was $0.156 \%$, while for longer journeys up to $9 \mathrm{~h}$, the incidence increased by approximately $80.0 \%$ to $0.283 \%$. In a similar study in Italy, Petrucci et al. (2005) found that for a shorter journey of $3.5 \mathrm{~h}$, the observed DOA was $0.24 \%$ and for longer journeys $(>5 \mathrm{~h}$ ) the mortality rate was $0.45 \%$. In a recent preliminary survey carried out in Brazilian summer conditions, the results indicated that for distances of 15 to $55 \mathrm{~km}$ the DOA varied from 0.13 to $0.26 \%$ (Simões et al., in preparation). These figures varied also in relation to the refreshment of birds by water shower treatment just after loading at the farm, but before the actual journey. The influence this water shower had on the birds welfare could be measured, since the mortality rate decreased by nearly half during longer distance journeys after the treatment. This fact may help to partially explain the high incidence of DOA in the present study, as shown in Table 6, since water showers were not performed before loading, demonstrating the importance of this unique technique in Brazilian conditions. The results shown in Table 6 are interesting and deserve further discussion. The PSE and DOA occurrences were highest for a short journey period without lairage and longer transport periods with lairage, respectively, although both are caused by thermal stress. It has been demonstrated that higher temperatures and relative humidity $(\mathrm{RH})$ are conditions that increase the rate of PSE meat, as recently shown by Simões et al. $(2009 \mathrm{a}, \mathrm{b})$ in birds transported by open truck under commercial Brazilian summer conditions. Meat samples from broilers located at the rear of the vehicle produced the highest percentage of PSE meat because of the higher temperatures and $\mathrm{RH}$ in comparison to those samples from birds located in the front and middle of the truck. The results shown in Table 6 indicate the importance of decreasing the temperature and $\mathrm{RH}$ during preslaughter management, which can be partially accomplished by water shower treatment at the farm and at the plant during lairage period. As shown by Guarnieri et al. (2002, 2004), this procedure is beneficial to the animals and consequently to the meat quality. Although the cause of death in DOA situations is heat stress, there is not much of a relationship between PSE 
meat and DOA (Table 6). In fact, the causes of mortality seem to be related to acute $(14.0 \%)$ and congestive $(37.0 \%)$ heart failure and trauma (32\%), as discussed in Petracci et al. (2006), suggesting that DOA is caused more by antemortem stressful situations rather than pre-existing pathological conditions. As the conditions of preslaughtering are aggravated by longer transport and lairage, birds find it difficult to lose heat by evaporation, particularly under high humidity, leading to heart failure.

\section{CONCLUSION}

The association of longer transport and longer lairage periods promoted higher

DOA, while PSE meat occurrence did not seem to follow similar parameters under the conditions of this experiment. Both DOA and PSE meat are caused by high temperature and high relative humidity conditions during transport. Official regulations are needed to control ante-mortem management, to create and maintain broiler welfare, to preserve meat quality, and to avoid the high rate of mortality.

\section{ACKNOWLEDGEMENTS}

The financial resources for the conduction of this study were supported by the project BioAgroPar financed by FINEP, SETI/PR, and Fundação Araucária/PR; and by $\mathrm{CNPq} /$ Brazil. DFM was under CAPES/MEC scholarship. MS and EII are currently Research Fellows.

\section{RESUMO}

O objetivo desse trabalho foi avaliar a influência do tempo de transporte e período de descanso antes do abate dos frangos na ocorrência das carnes PSE (Pale, Soft, Exudative: Pálido, Amolecido e Exsudativo) e DOA (Dead On Arrival: Morte Na Chegada) nas condições não comerciais durante o verão brasileiro. Frangos machos $(n=250)$ de uma linhagem comercial foram submetidos a diferentes periodos de jornada (30, 90 e $180 \mathrm{~min})$ e descanso $(0,90$ e $180 \mathrm{~min})$ antes do abate. A ocorrência do PSE foi maior em frangos submetidos tanto em tempos para as viagens curtas como para o de descanso enquanto que DOA foi mais pronunciada em condições de jornadas longas e maior periodo de descanso. A porcentagem da ocorrência do DOA foi maior ao se comparar com os resultados obtidas por empresas comerciais confirmando que os frangos são sensiveis às condições das viagens e de descanso a que são submetidos.

\section{REFERENCES}

Barbut, S. Sosnicki, A. A., Lonergan, S. M., Knapp, T., Ciobanu, D. C., Gatcliffe, L. J., Huff-Lonergan, E., Wilson, E.W. (2008), Progress in reducing the pale, soft and exudative (PSE) problem in pork and poultry meat. Meat Sci., 79, 46-63.

Bilgili, S. F.; Egbert, W. R.; Hoffman, D. L. (1989), Research note: effect of postmortem ageing temperature on sarcomere lengh and tenderness of broiler Pectoralis major. Poult. Sci., 68, 1588-1591.

Guarnieri, P. D.; Olivo, R.; Soares, A.; Ida, E. I.; Lara, J. A. F.; Shimokomaki, M. (2002), Bem estar animal e qualidade da carne das aves: uma exigência dos consumidores. Rev. Nac. da Carne, 26, 36-44.

Guarnieri, P. D., Soares, A. L., Olivo, R., Schneider, J. P., Macedo, R. M., Ida, E. I.; Shimokomaki, M. (2004), Preslaughter handling with water shower spray inhibits PSE (Pale, Soft, Exudative) broiler breast meat in a commercial plant. Biochemical and Ultrastructural observations. J Food Biochem, 28, 269-277.

Hamm, R. (1960), Biochemistry of meat hydration. Adv. Food Res. 10, 335-362.

Langer, R. O. S., Simões, G. S., Soares, A. L., Oba, A., Rossa, A., Shimokomaki, M., Ida, E. I. (2009), Broiler transportation conditions in a Brazilian commercial line and the occurrence of breast PSE (Pale, Soft, Exudative) meat and DFD-like (Dark, Firm, Dry) meat. Braz. Arch. Biol. Technol. Submitted, 2009

Mendes, A. A. (2001), Rendimento e qualidade da carcaça de frangos de corte. In: Conferência Apinco de Ciência e Tecnologia Avícolas, 29-31 maio, Campinas, São Paulo, Brasil, p.79-99.

Mitchell, M. A., Kettlewell, P. J. (1998), Physiological stress and welfare of broiler chickens in transit: solution not problem. Poultry Science, 77, 18031814.

Olivo, R., Soares, A. L., Ida, E. I., Shimokomaki, M. (2001), Dietary vitamin E inhibits poultry PSE and improves meat functional properties. J. Food Biochem., 25, 271-283.

Olivo, R. and Shimokomaki, M. (2006), Carne PSE em Frangos. In: Atualidades em Ciência e Tecnologia de Carnes Shimokomaki et al. eds., São Paulo: Varela, p. 95-104. 
Petracci, M., Bianchi, M., Caviani, C. (2005), Preslaughter factors affecting mortality, liveweight loss and carcass quality in broiler chickens. Proc. XVII Eur. Symp. Qual. Poul. Meat. Doorwerth, The Nederlands. p. 104-107.

Petracci, M., Bianchi, M., Cavani, C., Gaspari, Lavazza, P. (2006) Preslaughter mortality in broiler chickens, turkeys, and spent hens under commercial slaughtering. Poult Sci., 85, 1660-1664.

Simões, G. S., Rossa, A, Oba, A., Matsuo, T., Shimokomaki, M., Ida, E.I. (2009a). Transporte e ocorrência de PSE (Pale, Soft, Exudative) e a-DFD (Dark, Firm, Dry) em filés de peito de frango. Rev. Nac. da Carne, 23, 20-30.

Simões, G. S. Oba, A., Matsuo, T., Rossa, A., Shimokomaki, M., Ida, E. I. (2009b), Vehicle thermal microclimate evaluation during Brazilian summer broiler transport and the occurrence of PSE (Pale, Soft, Exudative) meat. Braz. Arch. Biol. Technol Submitted
Soares, A. L.; Lara, J. A. F.; Ida, A. I.; Guarnieri, P. D.; Olivo,R.; Shimokomaki, M. (2002),Variation in the colour of Brazilian broiler breast fillet. International Congress of Meat Science and Technology, 48, 540541.

Soares, A., L., Ida, E. I., Miyamoto, S., Blazquez, F. J. H., Olivo, R., Pinheiro, J. W. and Shimokomaki, M. (2003), Phospholipase A2 activity in poultry PSE, Pale, Soft, Exudative. J. Food Biochem., 27, 309-319.

Sosnicki, A.A. (1998). PSE-like syndrome in breast muscle of domestic turkeys: a review. J. Muscle Foods, 9, 13-23.

Warris, P. D., Bevis, E. A., S. N. Brown, Edwards, J. E. (1992), Longer journeys to processing plants are associated with higher mortality in chickens. Poul. Sci., 33, 201-206. 


\section{PÁGINA EM}

BRANCO 